\title{
How Do Rewards and Management Styles Influence the Motivation to Share Knowledge?
}

\author{
Harder, Mie
}

Document Version

Final published version

Publication date:

2008

License

CC BY-NC-ND

Citation for published version (APA):

Harder, M. (2008). How Do Rewards and Management Styles Influence the Motivation to Share Knowledge? Center for Strategic Management and Globalization. SMG Working Paper No. 6/2008

Link to publication in CBS Research Portal

\footnotetext{
General rights

Copyright and moral rights for the publications made accessible in the public portal are retained by the authors and/or other copyright owners and it is a condition of accessing publications that users recognise and abide by the legal requirements associated with these rights.

\section{Take down policy}

If you believe that this document breaches copyright please contact us (research.lib@cbs.dk) providing details, and we will remove access to the work immediately and investigate your claim.
} 
HOW DO REWARDS AND MANAGEMENT STYLES INFLUENCE THE MOTIVATION TO SHARE KNOWLEDGE?

Mie Harder

SMG WP 6/2008

February 12, 2008 
SMG Working Paper No. 6/2008

February 12, 2008

ISBN: 978-87-91815-19-5

Center for Strategic Management and Globalization Copenhagen Business School

Porcelænshaven 24

2000 Frederiksberg

Denmark

www.cbs.dk/smg 
HOW DO REWARDS AND MANAGEMENT STYLES

INFLUENCE THE MOTIVATION TO SHARE KNOWLEDGE?

\author{
Mie Harder \\ Center for Strategic Management and Globalization \\ Copenhagen Business School \\ Porcelænshaven 24, $1^{\text {st }}$ floor, 2000 Frederiksberg, Denmark \\ $(+45) 38153338$ \\ mh.smg@cbs.dk
}

Working Paper

February 12th 2008

\title{
ACKNOWLEDGEMENTS
}

Thanks to Nicolai J. Foss, Torben Pedersen, and Mia Reinholt, all affiliated with the Center for Strategic Management and Globalization (Copenhagen Business School), for valuable comments and feedback on earlier versions of this paper. 


\title{
HOW DO REWARDS AND MANAGEMENT STYLES \\ INFLUENCE THE MOTIVATION TO SHARE KNOWLEDGE?
}

\begin{abstract}
How to motivate knowledge sharing is of crucial importance to many companies. This paper analyzes individual knowledge sharing behavior in a self-determination theory (SDT) perspective. The primary aim is to explore what type of motivation predicts knowledge sharing behavior and how this type of motivation is affected by reward structures and management styles in organizations. The paper builds on survey and interview data from a pilot case study and provides statistical evidence of a strong positive relationship between autonomous motivation and knowledge sharing behavior. Furthermore, tangible rewards are found to correlate negatively with autonomous motivation for knowledge sharing. The more employees perceive knowledge sharing to lead to tangible rewards, the less they are autonomously motivated to share. On the other hand, a management style supportive of employees' needs for autonomy is found to promote autonomous motivation for knowledge sharing.
\end{abstract}

Keywords: autonomy support, knowledge sharing, motivation, rewards

Word count: 6.906 


\section{INTRODUCTION}

Scholars in the knowledge management field generally hypothesize that rewards encourage the knowledge sharing behavior of individuals (e.g. Argote et al., 2003; Bock \& Kim, 2002, Bock et al., 2005; Burgess, 2005; Cabrera \& Cabrera, 2005; Cabrera et al., 2006; Zárraga \& Bonache, 2003). Yet, contrary to common belief, the expected positive effect of tangible rewards often fails to materialize (Bock \& Kim, 2002; Cabrera et al., 2006). For example, Bock et al. (2005) hypothesize that "The greater anticipated extrinsic rewards are, the more favorable the attitude toward knowledge sharing will be" (p. 92). Their findings, however, go contrary to the hypothesis leading them to suggest "[..] that extrinsic rewards hinder rather than facilitate the formation of positive attitudes toward knowledge sharing" (Bock et al., 2005, p. 98). The dominant approaches to motivation in the knowledge management literature - drawing upon economic exchange theory, social exchange theory, and expectancy theory (Bock \& Kim, 2002; Bock et al., 2005; Cabrera \& Cabrera, 2005, Watson \& Hewett, 2006) - thus, have not been able to adequately explain the relationship between rewards and motivation to share knowledge.

Another subject that is under-researched in the knowledge management field is the influence of management styles on individuals' motivation to share knowledge. Here, management style refers to the interpersonal approach adopted by managers in dealing with employees. Although issues related to management style such as feedback (Bock et al., 2005; Cabrera \& Cabrera, 2002), job autonomy (Cabrera et al., 2006) and peer or supervisor support (Cabrera et al., 2006; McDermott \& O’Dell, 2001; Zárraga \& Bonache, 2003) are often addressed in studies, attempts at encompassing the wider notion of management style have not been made. Nevertheless, managers have different ways of dealing with employees, for example in terms of giving choices and being open to questions, and how this affects employees' motivation to share knowledge largely remains an open issue. 
Knowledge sharing is an important source of competitive advantage in firms (Argote \& Ingram, 2000; Davenport \& Prusak, 1998; Nonaka \& Takeuchi, 1995), and, therefore, understanding what motivates employees to share knowledge is essential (Osterloh \& Frey, 2000; Quigley et al., 2007). The present study contributes to the knowledge management literature by analyzing the motivation for knowledge sharing in a self-determination theory perspective (SDT: Deci \& Ryan, 1985; Deci et al., 1989). SDT is a prominent approach in social psychology that has received attention in both organizational science (Osterloh \& Frey, 2000) and behavioral economics (Frey, 1993, 1997; Frey \& Jegen, 2001). By introducing the notion of autonomous and controlled motivation, SDT presents a more refined and nuanced view of motivation compared to the approaches traditionally adopted in the knowledge management literature. Through the lens of SDT, this paper aims to further our understanding of how rewards and management styles influence employees' motivation to share knowledge.

Specifically, this paper develops and tests four hypotheses on the relationship between rewards, management styles, motivation and knowledge sharing behavior. First, the paper explores what type of motivation predicts actual sharing behavior. Second, the paper explores how tangible and acknowledgement rewards influence the motivation to share knowledge. Lastly, the paper examines how management styles influence motivation to share knowledge. The paper builds on a pilot case study with a Danish company in the IT consultancy sector. The analysis is based on survey and interview data.

\section{THEORETICAL FRAMEWORK AND DEFINITIONS}

\section{Knowledge sharing}

Knowledge sharing is commonly defined as "the process through which one unit [..] is affected by the experience of another" (Argote \& Ingram, 2000, p. 151). In this respect, a unit can be an individual, a group or an organization (Argote \& Ingram, 2000; Argote et al., 2003; Inkpen \& Tsang, 2005). Knowledge sharing is a process of social interaction (Levin \& Cross, 2004; Nonaka \& Takeuchi, 1995; Quigley et al., 2007) that shares many characteristics with voluntary work 
behaviors such as organizational citizenship behavior (OCB; Bolino, 1999; Brief \& Motowidlo, 1986). Organ (1988) defines OCB as "[...] individual behavior that is discretionary, not directly or explicitly recognized by the formal reward system, and that in the aggregate promotes the effective functioning of the organization" (cited in Bolino, 1999, p. 82). In summary, knowledge sharing is defined as the voluntary and social process of transferring, absorbing and reusing existing knowledge in order to serve an organizational end.

As a consequence of this definition and its emphasis on the voluntary and social nature of knowledge sharing, individual motivation becomes a main factor in explaining knowledge sharing behavior. This does not mean that managers cannot influence knowledge sharing. Indeed, managers can influence motivation to share knowledge in numerous ways and not the least via reward structures and management styles. However, the factors that motivate knowledge sharing are likely to differ from those that motivate more simple and measurable tasks (Osterloh \& Frey, 2000).

\section{Motivation}

Motivation refers to what makes people act in particular ways. Specific theories may have different approaches to the various factors influencing motivation, but many scholars agree that motivation is the psychological processes that cause the arousal, direction, intensity and persistence of behavior (Locke \& Latham, 2004; Mitchell, 1982; Pinder, 1998). This entails that motivation is a latent construct and that it is distinctively different from behavior. Motivation is the processes that lead to behavior, and these processes cannot be directly measured or observed.

Scholars commonly distinguish between intrinsic and extrinsic motivation. Individuals are said to be intrinsically motivated when they do an activity out of interest and satisfaction from the activity itself. On the other hand, individuals are extrinsically motivated when they perform an activity because it is instrumental to the achievement of some external consequence, such as a reward or the avoidance of punishment (Gagné \& Deci, 2005; Osterloh \& Frey, 2000).

A number of theoretical approaches address the issue of motivation in the light of socialenvironmental factors such as rewards and management styles (e.g. Bandura, 1977; Blau, 1964; 
Skinner, 1974; Vroom, 1964, see also reviews in Ambrose \& Kulik, 1999; Mitchell, 1982). However, SDT (Deci, 1971; Deci \& Ryan, 1985; Gagné \& Deci, 2005; Ryan \& Connell, 1989) was the first framework to specifically address the interplay between intrinsic and extrinsic motivation. SDT argues that people have innate needs for autonomy, competence and relatedness. Because external rewards can shift perceived locus of causality (PLOC) from internal to external, they can be perceived as controlling and may thwart feelings of autonomy (DeCharms, 1968). However, external rewards may also convey information about people's performance. Thereby, feelings of competence are promoted and PLOC may shift from external to internal, which enhances intrinsic motivation (Ryan, 1982).

SDT broadens the understanding of motivation by distinguishing between autonomous and controlled motivation (Gagné \& Deci, 2005; Vallerand \& Bissonette, 1992). SDT argues that external regulations under certain conditions can be internalized by the individual to form autonomous types of (extrinsic) motivation. When a behavior is internalized, PLOC shifts from external to internal, and the employee perceives that the behavior originates from himself. Intrinsic motivation is the fullest type of autonomous motivation. SDT, further, divides extrinsic motivation into four types that vary in the extent to which they are autonomous. Integrated and identified regulation are viewed as autonomous types, whereas introjected and external regulation are labeled as controlled types. Integrated regulation is the fullest type of internalization and people have the feeling that their behavior is self-determined and an integrated part of who they are. Identified regulation is also internalized, albeit, to a lesser extent than integrated regulation. When identified motivated, people feel that the behavior is in accordance with values and goals that are personally important for them. Introjected regulation is a relatively controlled type of internalized motivation. In this type of motivation, the employee has not fully accepted the values underlying the regulation. Rather, his or her motivation is based on ego-involvement and strive to maintain self-worth and gain approval from others. External regulation is the most controlled type of motivation. Externally regulated behaviors are based on external punishments and rewards (Gagné \& Deci, 2005; Ryan \& 
Deci, 2000). External and introjected regulation are combined to form a controlled motivation composite, while intrinsic, integrated and identified regulation are combined to form an autonomous motivation composite (Ryan \& Deci, 2000). This is illustrated in fig. 1. below. SDT argues that the internalization of external regulations depends on designing a work climate and promoting a management style that is autonomy supportive rather than controlling (Deci et al., 1994).

\section{INSERT FIGURE 1 ABOUT HERE}

\section{HYPOTHESES}

\section{Knowledge sharing}

Knowledge sharing is defined as a voluntary social behavior that shares characteristics with OCB. The link between autonomous motivation and voluntary behaviors have been studied by a number of scholars. For example, Gagné (2003) finds that college students and volunteer workers are more likely to engage in prosocial behaviors when their needs for competence, relatedness and autonomy are satisfied. Also, Ryan and Connell (1989) examine for what reasons people engage in pro-social behaviors and find that autonomous reasons are most important. They also find that the more autonomous the reasons are, the more empathy and moral reasoning is associated with the behavior. Therefore, they argue, pro-social behavior is more self-endorsed and valued by the employee when it is autonomously motivated. Assuming that employees engage more in knowledge sharing when they endorse and value that behavior, higher levels of autonomous motivation should be associated with higher levels of knowledge sharing.

Similarly, studies have shown that when autonomous motivation is undermined, individuals are less likely to engage in prosocial behaviors (Gagné \& Deci, 2005). For example, Fabes et al. (1989) find that children are less likely to exhibit helping behavior after they receive rewards for that behavior. Also, Kunda and Schwartz (1983) show that rewarding students for helping 
subsequently undermine their motivation to help. They argue that voluntary social behaviors are motivated by a sense of moral obligation which they describe as "[..] a different kind of intrinsic motivation: the desire to do the right thing as determined by our own beliefs and values" (Kunda \& Schwartz, 1983, p. 764). Furthermore, they propose that "[..] external pressures to help may reduce future spontaneous helping, because these pressures undermine and weaken people's sense of moral obligation" (p. 770) This notion of moral obligation is comparable to autonomous types of motivation since it is based on internalized values and goals. This suggests that if autonomous motivation for sharing knowledge is undermined or lacking, employees should be less likely to engage in this behavior.

Furthermore, Bolino (1999) proposes that people engage in citizenship behaviors (e.g. helping) for either altruistic or impression management reasons. Impression management reasons include for example self-promotion and image enhancement. Bolino (1999) suggests that behaviors motivated by impression management will have a less positive effect on organizational outcomes, since people are likely to invest less effort in the behavior. In other words "[..] individuals whose primary goal is to increase the welfare of the organization or others are likely to outperform those whose goal is to look good" (p. 90). In the SDT framework, impression management can be compared to controlled motivation based on ego-involvement (introjection). Conversely, the altruistic reasons given for engaging in OCB can be compared to autonomous types of motivation based on internalized values (Gagné \& Deci, 2005). Then, people who engage in knowledge sharing for autonomous reasons should do so with more effort and are more likely to be persistent in that behavior.

Despite the fact that the existing literature indicates that autonomous motivation promotes prosocial behaviors (Gagné \& Deci, 2005), the relationship between autonomous motivation and knowledge sharing has not been empirically studied. However, due to the similarities between knowledge sharing and other types of voluntary behaviors, there are reasons to believe that autonomous motivation will also promote sharing behaviors. Therefore, I hypothesize that: 
Hypothesis 1: The more autonomously motivated to share knowledge, the more employees will engage in knowledge sharing behaviors.

\section{Tangible rewards}

SDT argues that tangible rewards may undermine autonomous motivation. While this effect has not been studied for knowledge sharing behaviors, it has been supported in a number of other areas. For example, the undermining effect is supported in a number of experiments and meta analyses (Cameron et al., 2001; Deci, 1971; Deci et al., 1999a, 1999b). Also, similar conclusions are found in attribution theory (e.g. Fabes et al., 1989; Kunda \& Schwartz, 1983; Lepper et al., 1973), organizational science (Osterloh \& Frey, 2000) and behavioral economics (Frey, 1993, 1997; Frey \& Jegen, 2001).

Furthermore, studies have shown that the potential undermining effect of tangible rewards is especially evident when dealing with complex tasks (e.g. Deci \& Ryan, 1985; Erez et al., 1990). Similarly, research in related fields has found negative effects of tangible rewards and surveillance on creativity, problem solving and cognitive flexibility (e.g. Amabile et al., 1990; Amabile, 1998). Since knowledge is contextual and multifaceted, transferring and reusing it can be characterized as a complex task requiring cognitive flexibility (Davenport \& Prusak, 1998). Furthermore, although the level of interest in a task depends on the individual, initial interest is generally higher on complex tasks such as sharing knowledge (Osterloh \& Frey, 2000). Therefore, the autonomous motivation for knowledge sharing is especially susceptible to being undermined by the use of tangible rewards.

Studies of other pro-social behaviors seem to confirm this proposition. For example, a study has shown that tangible rewards such as bonus payments significantly reduce voluntary cooperation (Fehr \& Falk, 2002). Similarly, Gneezy and Rustichini (2000) studied the effect of offering a bonus to volunteer workers. Volunteers who collected donations for cancer research were given a percentage of the collected amount. Although it was made clear that the bonus was financed by the research team and did not reduce donations to the cancer societies, the amount collected was 
significantly lower in the rewarded groups than in the control group that was offered no reward. These findings mirror already mentioned studies by Fabes et al. (1989) and Kunda and Schwartz (1983) that also find negative effects of tangible rewards on prosocial motivation.

Nevertheless, contributions in the knowledge sharing literature generally hypothesize that tangible rewards have a positive effect on sharing behavior. In other words, if employees are paid more for sharing, they are supposed to share more knowledge. However, this effect fails to materialize. For example, Cabrera et al. (2006) find that tangible rewards have no significant effect on knowledge sharing, and Bock and Kim (2002) find that "[..] the attitude toward knowledge sharing is negatively related to the expected rewards. That is, expected rewards discourage the formation of a positive attitude toward knowledge sharing" (p. 19). This effect went counter to their initial hypothesis building on economic exchange theory, and they argue that the negative correlation is due to rewards being perceived as manipulative and controlling. In a subsequent study, Bock et al. (2005) again find a small but significant negative correlation between expected tangible rewards and positive attitudes toward knowledge sharing. These findings indicate that tangible rewards may harm knowledge sharing performance, but they fail to address the mediating role of motivation.

In summary, there are reasons to believe that the undermining effect of tangible rewards found in the SDT literature may also apply to knowledge sharing. In other words, tangible rewards are likely to be associated with lower levels of autonomous motivation for knowledge sharing. Therefore, I hypothesize that:

Hypothesis 2: The more employees perceive that knowledge sharing leads to tangible rewards, the less they will be autonomously motivated to share knowledge.

\section{Acknowledgement}

Most contributions from the motivation literature consent that acknowledgements have a positive effect on employees' motivation to perform a given activity. However, acknowledgement rewards are often labeled differently by different scholars even when they essentially refer to very 
similar concepts. For the sake of clarification, I consider acknowledgement to include notions such as verbal rewards, positive feedback, recognition and praise.

SDT argues that acknowledgements promote feelings of competence which make people perceive their behavior as more self-determined and enhance intrinsic motivation (Deci, 1971; Deci \& Ryan, 1985). This proposition is supported by numerous empirical studies. For example, Deci (1971) finds that verbal reinforcement and positive feedback tend to enhance students' intrinsic motivation. Also, Deci et al.'s (1999a) meta-analysis finds that verbal rewards significantly enhance intrinsic motivation and interest across 92 studies. The same conclusion is reached by Cameron et al. (2001) in their meta-analysis comprising 145 studies. Furthermore, social learning theory predicts a similar effect of acknowledgement rewards (Bandura, 1977). The reasoning here is that acknowledgement such as positive feedback and praise reinforce a given behavior by promoting employees' self-efficacy.

The positive effect of acknowledgement is also recognized in other fields of study such as economics. For example, Frey (1997) argues that when employees perceive an external intervention as an acknowledgement of their general competence, it will increase their work moral and intrinsic motivation for the task. This effect manifests itself in different voluntary social behaviors; e.g. people's willingness to donate blood. Studies report that when donors are paid, they generally give less blood. In contrast, giving non-monetary inducements that signal acknowledgement or recognition of the contribution raises intrinsic motivation to give.

A number of studies in the knowledge sharing literature also support this prediction. For example, Cabrera et al. (2006) find that people are more inclined to share knowledge with others to the extent that approval from managers and colleagues is expected. In fact, this is found to be the most important organizational variable predicting knowledge sharing behavior. Moreover, Bock et al. (2005) find that appraisal and feedback has a significant positive influence on subjective norms for knowledge sharing by promoting employees' sense of competence and self-worth. 
Although, the effect of acknowledgement on autonomous motivation for knowledge sharing has not been addressed specifically in prior studies, it must be assumed that acknowledgement promotes the satisfaction of employees' needs for competence and thereby raises their autonomous motivation to share. In summary, I hypothesize that:

Hypothesis 3: The more employees perceive that knowledge sharing leads to acknowledgement rewards, the more they will be autonomously motivated to share knowledge.

\section{Autonomy support}

The role of management styles has received little attention in the knowledge sharing literature. One exception is Cabrera et al. (2006) who find that management being supportive of and encouraging knowledge sharing is an important predictor of employees' engagement in knowledge sharing behavior. However, this contribution only reflects one particular aspect of management support and it does not directly take into account the role of employee motivation.

In the SDT literature, scholars suggest that a management style supportive of employees needs for autonomy (i.e. managerial autonomy support) is an important predictor of autonomous motivation (Deci et al., 1989; Gagné \& Deci, 2005; Vansteenkiste et al., 2004). Autonomy support refers to "[..] the general interpersonal orientation used by one's manager or work group supervisor" and "[..] involves the supervisor understanding and acknowledging the subordinate's perspective, providing meaningful information in a nonmanipulative manner, offering opportunities for choice, and encouraging self-initiation" (Baard et al., 2004, p. 2048).

Other theoretical approaches include notions similar to autonomy support (e.g. Hackman \& Oldham, 1976; Herzberg, 1968; Latham, 2004). Also, in studies of prosocial behaviors, managers who are considerate of employees are expected to promote prosocial acts and reciprocity norms (Brief \& Motowidlo, 1986). Consideration can, in this respect, be compared to acknowledging employees' perspective which is part of managerial autonomy support. Moreover, participative 
management styles, in contrast to more authoritarian ones, have been associated with lower employee stress levels and higher job satisfaction (Kim, 2002; Lind \& Otto, 1994).

The effect of autonomy support is studied by several scholars within the SDT field. For example, a study by Black and Deci (2000) finds that perceived autonomy support of university instructors predicts students' autonomous motivation as well as their course performance. A study conducted by Baard, Deci and Ryan (2004) in two work organizations also shows that perceived autonomy support of managers predicts satisfaction of employees' needs for competence, autonomy and relatedness. Need satisfaction, then, predicts better performance evaluations. Similarly, two recent studies link autonomy support to pro-social behavior among college students and volunteer workers (Gagné, 2003).

Nevertheless, the influence of autonomy support on employees' autonomous motivation to share knowledge has not been studied. Due to the similarities between prosocial behaviors and knowledge sharing it seems reasonable to hypothesize that autonomy support will also predict autonomous motivation for knowledge sharing. Thus, I hypothesize that:

Hypothesis 4: The more employees perceive that managers are autonomy supportive, the more they will be autonomously motivated to share knowledge.

The four hypotheses are summarized in figure 2 below.

\section{INSERT FIGURE 2 ABOUT HERE}

\section{METHODOLOGY}

\section{Case and procedure}

The paper is based on a single case study conducted with a Danish company in the IT consultancy sector. At the time of the study, the company had 40 employees and the majority of employees worked as consultants. The company operates in a highly knowledge based industry and 
its competitive advantage largely relies on the willingness and ability of its employees to share and reuse knowledge across the organization. Therefore, the company was identified as a relevant pilot case.

The study builds on survey data and personal interviews. The survey was conducted using internet based software and was sent to 34 employees. Employees hired within the last month before conducting the survey and managers were not included. A week before the survey, all employees were contacted by e-mail and encouraged to participate in the survey by the one of the directors. Furthermore, after inviting employees to participate, I sent out two personal reminders to those who had not responded after one and two weeks, respectively. 32 employees participated representing a response rate of $94 \%$. Questions are generally structured as 7 point Likert scales, e.g. ranging from "strongly disagree" to "strongly agree". In order to avoid missing values, it was mandatory for respondents to answer all questions. Making items mandatory, also, forces respondents to think about all the questions. A pre-test (Andersen, 2002; Gorard, 2003) was conducted with 9 respondents (primarily university students). Comments and criticism from pre-test participants were used to minimize ambiguities in the questionnaire. Relationships between variables are studied using correlation and regression statistics. Since the study is not experimental or longitudinal, the time-order of relationships between variables is inferred theoretically.

Semi-structured interviews were conducted with six employees after finishing the survey. Respondents with different nationalities and age profiles were selected in order to ensure that the interview data would be representative of the organization. An interview guide was followed strictly with all respondents in order to improve comparability of the results (Barribal \& While, 1994; Kvale, 1994). In order to enable data triangulation, the interviews addressed the same issues as the survey did (Yin, 2003). The interviews began with quite open questions encouraging the respondent to give his or her own opinion about the main factors influencing his or her motivation to share knowledge. When having exhausted the subjects or factors that the respondent brought up 
himself (or herself), I posed more specific questions to make sure that the concepts of interest to the study were all covered. The interviews were recorded and transcribed.

\section{Measurements}

Items in the questionnaire are adapted from measures that have been validated in prior research. For a complete list of survey items see appendix one.

Knowledge sharing. The dependent variable, knowledge sharing, is based on four items relating to employees' self-reported knowledge contribution and knowledge seeking. The four items are adapted from a measurement used by Cabrera et al. (2006). The items include the following examples "When I have knowledge that might be relevant for others in the company, I do what I can to make it available to them" and "When I encounter a work related problem, I seek knowledge and help from my colleagues". The internal reliability (Cronbach's alpha) of this scale is .67 which is just below the .70 that is normally regarded as reliable (Bryman \& Cramer, 1999; Tabachnick \& Fidell, 2001). The reliability could probably be improved by adding more items. In short scales, it is common to find lower alpha values (Briggs \& Cheek, 1986).

Perceived tangible rewards. The perceived tangible rewards scale consists of three items measuring the extent to which employees perceive that their engagement in knowledge sharing leads to "increased chance of fringe benefits", "better chances for advancements or promotion" and "salary increases". Burgess (2005) measures organizational credit for knowledge sharing in a comparable manner, however, without separating different types of rewards into sub-scales. The internal consistency of the perceived tangible rewards scale is .68.

Perceived acknowledgement rewards. The scale for perceived acknowledgement rewards, similarly, is based on three items measuring the extent to which employees perceive that knowledge sharing behavior leads to "positive feedback from my manager(s)", "acknowledgement from my colleagues" and "acknowledgement from my manager(s)". Burgess (2005) includes similar items. The scale has an alpha value of .87 . 
Autonomy support. In order to assess perceived autonomy support, I used an adaptation of the six-item version of the work climate survey developed by Deci, Connell and Ryan (1989). The items include examples such as "I feel that my manager(s) provide me choices and options about how to do my job and how to handle problems I encounter" and "My manager(s) tries to understand how I see things before suggesting a new way to do things". The items all refer to the general orientation of managers and not their approach to knowledge sharing in particular. Variations of this scale is used in a number of studies, for example Gagné (2003) and Black and Deci (2000). Internal consistency of the scale is .87 on this sample.

Autonomous motivation. In order to assess how autonomously motivated employees are for sharing knowledge, I used an adaptation of the self-regulation questionnaire (Ryan \& Connell, 1989). Respondents are asked to rate how true each of 12 reasons are for why they share knowledge. The different reasons given represent intrinsic (e.g. "I enjoy doing so"), identified (e.g. "Because sharing knowledge is an important value for me"), introjected (e.g. "I want my manager(s) to think well of me") and external (e.g. "It may help me get promoted") types of motivation. There are no items referring to integrated motivation. In the SDT tradition, integrated motivation has not been included in questionnaires because of the difficulty of formulating statements that adequately grasp the concept. In accordance with the SDT practice, I have chosen not to include integrated motivation but rather to rely on the existing self-regulation scale which has been validated in numerous studies. The intrinsic and identified items together represent the scale for autonomous motivation (total of 6 items). The scale has an internal consistency of .83.

The remaining 6 items relating to introjected and external types of motivation constitute the controlled motivation scale, which is used as a control variable. The scale has an alpha value of .88 .

\section{FINDINGS}

The correlations between main variables are presented in table 1. 


\section{Knowledge sharing}

Using Pearson's product-moment correlation coefficient, strong support is found for hypothesis 1. After entering the four control variables (age, gender, duration of employment and controlled motivation), autonomous motivation and self-reported knowledge sharing are strongly and significantly correlated $(\mathrm{r}=0.58, \mathrm{p}<0.01)$. Higher levels of autonomous motivation, therefore, are associated with higher levels of knowledge sharing behavior. A correlation coefficient of 0.58 specifically means that $34 \%\left(0.58^{2}\right)$ of the variance in knowledge sharing behavior can be explained by variance in levels of autonomous motivation.

In order to confirm that autonomous motivation is indeed the most important type of motivation predicting knowledge sharing behavior, I also tested whether controlled motivation would influence knowledge sharing. After controlling for age, duration of employment, gender and the influence of autonomous motivation, controlled motivation showed only a small and nonsignificant negative correlation with knowledge sharing $(\mathrm{r}=-0.24, \mathrm{p}=0.22)$. Therefore, autonomous motivation is by far the strongest and most significant predictor of knowledge sharing in this sample.

\section{INSERT TABLE 2 ABOUT HERE}

Studying the highest scoring reasons for sharing knowledge also shows a clear pattern (table 2). As mentioned, respondents were asked to score to what extent they agreed with 12 different reasons for sharing knowledge on a 7 point Likert scale. When the 12 items are ranked according to mean scores, identified and intrinsic reasons occupy the top positions, while introjected and external reasons receive the lowest ranks. This indicates that when employees are asked to assess their own motivation, on average they assign most importance to autonomous reasons for knowledge sharing. 
The interview data also supports the hypothesis. When asked what motivates them to share knowledge, all respondents' initial replies centered on one or more of the following: personal interest in learning, satisfaction from helping colleagues, and a feeling that sharing knowledge is just a natural part of the job. No one mentioned the expectation of tangible rewards or formal recognition as their motivation to share knowledge. For example, one respondent described his motivation to share knowledge with colleagues in this way: "Maybe I have something to learn from that and if I can help him I feel good about myself. It is, I don't know, just the feeling that I did something good." It is clear from this line of reasoning that the respondent relates his knowledge sharing behavior to an autonomous type of motivation. E.g. the personal learning objective can be categorized as an interest-based type of intrinsic motivation (Gagné \& Deci, 2005). Likewise, the notion of "doing something good" can be ascribed to identified motivation, where the respondent personally identifies with the value and importance of sharing knowledge.

Other respondents place more emphasis on knowledge sharing being a natural part of their jobs. For example, one respondent says: "I think the way I see it, if I do have the knowledge, I feel that I have the obligation to help. [..] And I think it's more or less the normal behavior". This type of reasons can also be ascribed to identified motivation; i.e. an identification with the values underlying knowledge sharing.

\section{Tangible rewards}

Hypothesis 2 is also supported. After controlling for age, duration of employment, gender and controlled motivation, the findings show a medium strong and significant negative correlation between perceived tangible rewards and autonomous motivation $(\mathrm{r}=-0.39, \mathrm{p}<0.05)$. Thus, $15 \%$ $\left(0.39^{2}\right)$ of the variance in autonomous motivation for knowledge sharing can be explained by variance in perceived tangible rewards. This confirms that tangible rewards can reduce autonomous motivation for knowledge sharing.

In the interviews, none of the respondents had experienced that knowledge sharing led to tangible rewards in the case company. Therefore, I asked how the introduction of tangible rewards 
for knowledge sharing would potentially influence their motivation to share. Only one of the six respondents felt that it would increase his motivation. He remarked that "When you get rewarded you always tend to repeat and improve the actions that you get rewarded for". Out of the five remaining respondents, three held that tangible rewards would have no influence on their motivation, while two stated that it would decrease their motivation. These two respondents said that they would perceive it as a "manipulation" and as "being forced" to do something. While it is not evident that all people respond this negatively to tangible rewards, this is nonetheless an example of how rewards can have a controlling effect on employees and, ultimately, can undermine their motivation (Bock et al., 2005; Fehr \& Falk, 2002; Gagné \& Deci, 2005; Kohn, 1993).

\section{Acknowledgement}

Hypothesis 3 is not supported in the correlation analysis. However, while there is no statistical support for the hypothesis, most of the interviewees feel that acknowledgement has a positive influence on their motivation to share knowledge. For example, one respondent emphasizes acknowledgements as a way to confirm that his ideas and knowledge are relevant: "I think acknowledgement is motivating for anyone. [..] I don't know if it's very important but I can see that it does affect my motivation in the sense that each time I say something correct and people go like "yeah", I will be more motivated to keep on doing that and finding out the right information and sharing it". In this type of situation, acknowledgements convey information to the employee about the value of his behavior, which in turn raises his sense of competence and his autonomous motivation (Gagné \& Deci, 2005). "If an environmental event enhances people's perception of competence, their intrinsic motivation will increase" (Ryan, 1982, p. 450). Other respondents also feel motivated by acknowledgements, but they do not in the same way relate it to their perception of competence.

In summary, neither the survey nor the interview data significantly support the hypothesis. While the interview analysis may indicate that acknowledgement raises motivation, it is difficult to distinguish from the responses what kind of motivation it creates. 


\section{Autonomy support}

Strong support is found for hypothesis 4. After entering the four control variables, a correlation of $0.58(\mathrm{p}<0.005)$ was found between autonomy support and autonomous motivation for knowledge sharing. Thus, higher levels of perceived managerial support are associated with higher levels of autonomous motivation for knowledge sharing. To be exact, $34 \%\left(0.58^{2}\right)$ of the variance in autonomous motivation for knowledge sharing is caused by variance in perceived autonomy support.

While the survey shows that autonomy support strongly promotes autonomous motivation for knowledge sharing, the findings in the interview data are not as unambiguous. Since autonomy support refers to a general approach adopted by managers and is not specifically linked to knowledge sharing, it is likely to promote autonomous motivation for a number or behaviors (Baard et al., 2004; Deci, 1989; Gagné 2003). Therefore, it is difficult to distinguish from some interview statements if the motivation induced by autonomy support is general or specific for knowledge sharing. The interview data, nevertheless, indicates support for the hypothesis.

Generally, respondents focus on being given choices and autonomy in performing activities, being given a meaningful rationale for assignments and on managers showing confidence in their ability to do well. All of which are included in the notion of managerial autonomy support. For example, one respondent described a good manager in this way:

"He's quite open in telling me what is the situation and what is the objective. He lets you participate and lets you be part of the whole picture. When I'm able to understand that, I can understand much better what are the parameters of the task. If I have to do a small task on a big thing, I can see just where it fits [... because I'm able to comprehend the bigger picture. Now, in another management style [..] it would be much more like 'can you do this for me'. [..] Then I would be forced to ask more questions and I would just feel a lot more uncomfortable. Because I wouldn't feel like I'm contributing with something. I'm going to feel like I'm just doing that little thing. And it's probably the 
same task. But in the one I would have more possibility to decide by myself and in the other one I would be more restricted".

The respondent describes a management style characterized by giving a meaningful rational for tasks and relates it to a kind of motivation, where he feels less restricted and more able to decide by himself. The management style he refers to reflects elements of the autonomy supportive manager (Gagné \& Deci, 2005). Also, the motivation he describes can be characterized as an autonomous kind of motivation, since he emphasizes the absence of control (feeling less restricted) and the perceived self-determined nature of behavior (being able to decide by himself). This suggests that autonomy supportiveness of managers is, in fact, related to employees' autonomous motivation.

In sum, the statistical analysis strongly and significantly supports the hypothesis. Higher levels of perceived managerial autonomy support are indeed associated with higher levels of autonomous motivation to share knowledge. Also, interview data indicates that elements of autonomy support, such as giving a meaningful rationale and providing choices about how to do assignments, are important for employees' autonomous motivation to share knowledge.

\section{Summary and model}

In order to further strengthen the analysis, regression analysis is used to assess how much variance in knowledge sharing and autonomous motivation can be explained by the set of independent variables (IVs) and to analyze the relative contribution of each of the IVs (Tabachnick \& Fidell, 2001). The results from the regression analyses are summarized in table 3 and 4.

\section{INSERT TABLE 3 ABOUT HERE}

In order to isolate the contributions made by the set of IVs, the four control variables are entered into the equation first (step one). Then the independent variables of interest are entered in step two. This enables an assessment of how much variance is explained by the variables of interest 
after the effects of control variables are removed $\left(\Delta \mathrm{R}^{2}\right)$. In the case of knowledge sharing, the model as a whole (incl. control variables) explains $41 \%$ of the variance in knowledge sharing behavior (adjusted $\mathrm{R}^{2}$ ). $27 \%$ of the variance in knowledge sharing can be explained by autonomous motivation alone, when the effect of control variables has been taken into account (adjusted $\Delta \mathrm{R}^{2}$ ).

The second column in table 3 shows the standardized regression coefficients (betas) of each of the variables. As expected, autonomous motivation makes the strongest unique contribution to the prediction of knowledge sharing behavior (beta $=0.53, \mathrm{p}<0.01$ ). The only other unique contribution to predicting knowledge sharing comes from age (beta $=-0.41, \mathrm{p}<0.05$ ).

\section{INSERT TABLE 4 ABOUT HERE}

The regression analysis for autonomous motivation is presented in table IV. The IVs of interest explain $33 \%$ of the variance in autonomous motivation (adjusted $\Delta \mathrm{R}^{2}$ ). In accordance with the results from the correlation analysis, the most significant predictors of autonomous motivation are tangible rewards (beta $=-0.47, \mathrm{p}<0.1$ ) and autonomy support (beta $=0.53, \mathrm{p}<0.01)$. Also, in concurrence with the correlation analysis, it is clear that autonomy support makes the strongest unique contribution to explaining autonomous motivation when the variance explained by all the other variables is controlled for. In summary, the regression analysis confirmed the support for hypotheses 1, 2, and 4 . Table 5 summarizes the results from the analyses.

INSERT TABLE 5 ABOUT HERE

\section{CONCLUDING DISCUSSION}

Strong support has been found for three of the hypotheses. However, there was no correlation between acknowledgement and autonomous motivation. This goes counter to the general findings in the motivation literature where a number of studies have found that acknowledgement is 
positively related to autonomous motivation (e.g. Cameron et al., 2001; Deci, 1971; Frey, 1997). One explanation for the lack of support may be that a part of the acknowledgement employees experience is perceived as controlling rather than informative. Ryan (1982) argues that acknowledgements as other types of external rewards can be either informational or controlling. "[T] he more we interpret what someone says as pressure to achieve a particular outcome [..] the less likely we are to be intrinsically motivated to perform that activity" (Ryan, 1982, p. 451). Another explanation could be that autonomy support moderates the relationship between acknowledgements and autonomous motivation, since the organizational climate affects how rewards are perceived (Deci et al., 1994). However, such an interaction effect was not found in this sample. This suggests that further specification of the concept may be needed in order to disentangle the controlling and informational effects of acknowledgements in future studies. Also, future research may achieve more conclusive results by using larger samples.

\section{Implications for research}

The findings in this paper provide at least three important implications for knowledge management research. First, the study indicates that individual motivation mediates the relationship between contextual variables and knowledge sharing behavior. As such, there were no direct correlations between the independent variables (rewards and management styles) and knowledge sharing. This implies that motivation is, in fact, an important factor in understanding and explaining knowledge sharing performance in organizations. Also, contrary to common belief, the type of motivation is not irrelevant. This study suggests that only autonomous types of motivation predict actual sharing behavior. Therefore, future research on knowledge sharing should not only address motivation as a mediating variable, but should also take into account the distinction between controlled and autonomous types of motivation.

Second, the findings indicate that tangible rewards may have a negative influence on employees' autonomous motivation to share knowledge and, ultimately, on their knowledge sharing behavior. This is in stark contrast to the general perspectives in the knowledge management 
literature and common belief among practitioners (Heath, 1999). As such, these findings question the dominant approach to motivating knowledge sharing and warrant more critical scrutiny of the effects of tangible rewards. Thus, future studies may elaborate on these findings in larger scale studies in order to examine more thoroughly the conditions under which tangible rewards are suitable or unsuitable for motivating knowledge sharing.

Lastly, this study suggests that management style is a significant predictor of individuals' motivation to share knowledge. In fact, an autonomy supportive management style is the most important contextual variable predicting autonomous motivation for knowledge sharing in this sample. These findings are important considering the relatively under emphasized role of management styles in the knowledge management literature. In other words, it seems that the interpersonal approach adopted by managers merits more attention than it has previously received. 


\section{REFERENCES}

Amabile, T. (1998). How to kill creativity. Harvard Business Review, September-October, 77-87

Amabile, T., Goldfarb, P. and Brackfield, S. (1990). Social influence on creativity: evaluation, coaction, and surveillance. Creativity Research Journal, 3, pp. 6-21.

Ambrose, M. L. and Kulik, C. T. (1999). Old friends, new faces: motivation research in the 1990s. Journal of Management, 25 (3), pp. 231-292

Andersen, I. (2002). Den skinbarlige virkelighed - om vidensproduktion i samfundsvidenskaberne. 2. udgave, Frederiksberg: Samfundslitteratur

Argote, L. and Ingram, P. (2000). Knowledge Transfer: A basis for competitive advantage in firms. Organizational Behavior and Human Decision Processes, 82(1), pp. 150-169

Argote, L., McEvily, B. and Reagans, R. (2003). Managing Knowledge in Organizations: An integrative framework and review of emerging themes. Management Science. 49, (4), pp. $571-582$

Bandura, A. (1977). Social Learning Theory. New Jersey: Prentice Hall.

Barribal, L. and While, A. (1994). Collecting data using a semi-structured interview: a discussion paper. Journal of Advanced Nursing, 19, pp. 328-335

Baard, P. P., Deci, E. L. and Ryan, R. M. (2004). Intrinsic need satisfaction: A motivational basis of performance and well-being in two work settings. Journal of Applied Social Psychology, 34(10), pp. 2045-2068

Black, A. E. and Deci, E. L. (2000). The effects of instructors' autonomy support and students' autonomous motivation on learning organic chemistry: a self-determination theory perspective. Science Education, 84, pp. 740-756.

Blau, P. M. (1964). Exchange and power in social life. New York: John Wiley \& Sons.

Bock, G. W. and Kim, Y.G. (2002). Breaking the myths of rewards: An exploratory study of attitudes about knowledge sharing. Information Resources Management Journal, 15(2), Apr-Jun, pp. 14-21 
Bock, G. W., Zmud, R.W., Kim, Y.G. and Lee, J.N. (2005). Behavioral intention formation in knowledge sharing: examining the roles of extrinsic motivators, social-psychological forces, and organizational climate. MIS Quarterly, 29(1), pp. 87-111

Bolino, M. C. (1999). Citizenship and impression management: Good soldiers or good actors? Academy of Management Review, 24(1), pp. 82-98

Brief, A. P. and Motowidlo, S. J. (1986). Prosocial organizational behaviors. Academy of Management Review, 11(4), pp. 710-725

Briggs, S. R and Cheek, J. M. (1986). The role of factor analysis in the development and evaluation of personality scales. Journal of Personality. 54, pp. 106-148

Bryman, A. and Cramer, D. (1999). Quantitative data analysis with SPSS Release 8 for Windows : a guide for social scientists. London: Routledge

Burgess, D. (2005). What motivates employees to transfer knowledge outside their work unit? Journal of Business Communication, 42(4), pp. 342-348

Cabrera, A., Collins, W. C. and Salgado, J. F. (2006). Determinants of individual engagement in knowledge sharing. International Journal of Human Resource Management, 17(2) February, pp. 245-264

Cameron, J., Banko, K. M. and Pierce, W. D. (2001) Pervasive negative effects of rewards on intrinsic motivation: the myth continues. The Behavior Analyst, 24, pp. 1-44

Davenport, T. H. and Prusak, L. (1998). Working Knowledge. How organizations manage what they know. Boston, Massachusetts: Harvard Business School Press.

DeCharms, R. (1968). Personal Causation: The internal affective determinants of behavior. New York: Academic Press

Deci, E. L. (1971). Effects of externally mediated rewards on intrinsic motivation. Journal of Personality and Social Psychology, 18, pp. 105-115.

Deci, E. L. and Ryan, R. M. (1985). Intrinsic Motivation and Self-Determination in Human Behavior. New York: Plenum Press. 
Deci, E. L., Connell, J.P. and Ryan, R. M. (1989). Self-determination in a work organization. Journal of Applied Psychology, 74(4), pp. 580-590

Deci, E. L., Eghrari, H., Patrick, B. and Leone, D. R. (1994). Facilitating internalization: the selfdetermination theory perspective. Journal of Personality, 62, pp. 119-142

Deci, E. L., Koestner, R. and Ryan, R. M. (1999a). A meta-analytic review of experiments examining the effects of extrinsic rewards on intrinsic motivation. Psychological Bulletin, 125(6), pp. 627-668

Deci, E. L., Koestner, R. and Ryan, R. M. (1999b). The undermining effect is a reality after all extrinsic rewards, task interest, and self-determination: Reply to Eisenberger, Pierce and Cameron (1999) and Lepper, Henderlong, and Gingras (1999). Psychological Bulletin, 125(6), pp. 692-700

Deci, E. L. and Ryan, R. M. (2000). The 'what' and 'why' of goal pursuits: human needs and the self-determination of behavior. Psychological Inquiry, 11(4), pp. 227-268

Erez, M., Gopher, D. and Arzi, N. (1990). Effects of goal difficulty, self-set goals, and monetary rewards on dual task performance. Organizational behavior and human decision processes, 47 , pp. $247-269$

Fabes, R. A., Fultz, J., Eisenberg, N., May-Plumlee, T. and Christopher, F. S. (1989). Effects of rewards on children's prosocial motivation: a socialization study. Development Psychology, 25(4), pp. 509-515

Fehr, E. and Falk, A. (2002). Psychological foundations of incentives. European Economic Review, 46, pp. $687-724$

Felin, T. and Hesterly, W. S. (2007). The knowledge-based view, nested heterogeneity, and new value creation: philosophical considerations on the locus of knowledge. Academy of Management Review, 32(1), pp. 195-218

Frey, B. S. (1993). Motivation as a limit to pricing. Journal of Economic Psychology, 14, pp. 635664 
Frey, B. S. (1997). Not just for the money. An economic theory of personal motivation. Edward Elgar Publishing. United Kingdom: Cheltenham.

Frey, B. S. and Jegen, R. (2001). Motivation crowding theory. Journal of Economic Surveys, 15(5), pp. $589-603$

Gagné, M. (2003). The role of autonomy support and autonomy orientation in prosocial behavior engagement. Motivation and Emotion, 27(3), pp. 199-223

Gagné, M. and Deci, E. L. (2005). Self-determination theory and work motivation. Journal of Organizational Behavior, 26, pp. 331-362

Gneezy, U. and Rustichini, A. (2000). Pay enough or don't pay at all. The Quarterly Journal of Economics. August 2000, pp. 791-810

Gorard, S. (2003). Quantitative Methods in Social Science. New York: Continuum

Hackman, J. R. and Oldham, G. R. (1976). Motivation through the design of work: test of a theory. Organizational Behavior and Human Performance, 16, pp. 250-279

Heath, C. (1999). On the Social Psychology of Agency Relationships: Lay Theories of Motivation Overemphasize Extrinsic Incentives. Organizational Behavior and Human Decision Processes, 78(1), pp. 25-62

Herzberg, F. (1968). One more time: How do you motivate employees? Harvard Business Review. January-February 1968, pp. 53-62.

Inkpen, A. and Tsang, E. W. K. (2005). Social capital, networks, and knowledge transfer. Academy of Management Review, 30(1), pp. 146-165

Kim, S. (2002). Participative management and job satisfaction: Lessons for management leadership. Public Administration Review, 62(2), pp. 231-241

Kohn, A. (1993). Why incentive plans cannot work. In Harvard Business Review. SeptemberOctober 1993, pp. 54-63

Kunda, Z. and Schwartz, S. H. (1983). Undermining intrinsic moral motivation: external reward and self-presentation. Journal of Personality and Social Psychology, 45(4), pp. 763-771 
Kvale, S. (1994). Interview: En introduktion til det kvalitative forskningsinterview. København: Hans Reitzels Forlag.

Latham, G. P. (2004). The motivational benefits of goal-setting. Academy of Management Review, 18(4), pp. 126-129

Lepper, M. R., Greene, D. and Nisbett, R. E. (1973). Undermining children's intrinsic interest with extrinsic reward: a test of the "overjustification" hypothesis. Journal of Personality and Social Psychology, 28(1), pp. 129-137

Levin, D. Z. and Cross, R. (2004). The Strength of Weak Ties You Can Trust: The Mediating Role of Trust in Effective Knowledge Transfer. In Management Science, 50(11), pp. 1477-1490

Lind, S. L. and Otto, F. L. (1994). Management styles, mediating variables and stress among HRD professionals. Human Resource Development Quarterly, 5(4), pp. 301-316

Locke, E. A. and Latham, G. P. (2004). What should we do about motivation theory? Six recommendations for the twenty-first century. Academy of Management Review, 29(3), pp. $388-4036$

McDermott, R. and O’Dell, C. (2001). Overcoming cultural barriers to sharing knowledge. Journal of Knowledge Management, 5(1), pp. 76-85

Mitchell, T. R. (1982). Motivation: New directions for theory, research, and practice. Academy of Management Review, 7(1), pp. 80-88

Nonaka, I. and Takeuchi, H. (1995). The Knowledge Creating Company. How Japanese Companies Create the Dynamics of Innovation. New York: Oxford University Press

Organ, D. W. (1988). Organizational Citizenship Behavior: The good soldier syndrome. Lexington, MA: Lexington Books.

Osterloh, M. and Frey, B. S. (2000). Motivation, Knowledge Transfer, and Organizational Forms. In Organizational Science. 11(5), Sept.-Oct., pp. 538-550

Pinder, C. C. (1998). Work motivation in organizational behavior. Upper Saddle River, N.J.: Prentice Hall 
Quigley, N. R., Tesluk, P., Locke, E. and Bartol, K. (2007). A multilevel investigation of motivational mechanisms underlying knowledge sharing and performance. Organizational Science, 18(1), pp. 71-88

Ryan, R. M. (1982). Control and information in the intrapersonal sphere: an extension of cognitive evaluation theory. Journal of Personality and Social Psychology, 43(3), pp. 450-461

Ryan, R. M. and Connell, J. P. (1989). Perceived locus of causality and internalization: Examining reasons for acting in two domains. Journal of Personality and Social Psychology, 57, pp. $749-761$

Ryan, R. M. and Deci, E. L. (2000). Self-determination theory and the facilitation of intrinsic motivation, social development, and well-being. American Psychologist, 55(1), pp. 68-78

Skinner, B. F. (1974). About Behaviorism. Random House.

Tabachnick, B. G. and Fidell, L.S. (2001). Using Multivariate Statistics, $4^{\text {th }}$ edition. Boston: Allyn and Bacon.

Vallerand, R. J. and Bissonette, R. (1992). The Intrinsic, extrinsic and amotivational styles as predictors of behavior: a prospective study. Journal of Personality, 60(3), pp. 599-620

Vansteenkiste, M., Simons, J., Lens, W., Sheldon, K. M. and Deci, E. L. (2004). Motivating Learning, Performance, and Persistence: The Synergistic Effects of Intrinsic Goal Contents and Autonomy Supportive Contexts. Journal of Personality and Social Psychology, 87(2), pp. $246-260$

Vroom, V. H. (1964). Work and Motivation. New York: John Wiley.

Watson, S. and Hewett, K. (2006). A multi-Theoretical Model of Knowledge Transfer in Organizations: Determinants of Knowledge Contribution and Knowledge Reuse. Journal of Management Studies, 43(2), pp. 141-173

Yin, R. K. (2003). Case Study Research - Design and Methods, 3rd Edition, Thousand Oaks: Sage Publications, Inc. 
Zárraga, C. and Bonache, J. (2003). Assessing the team environment for knowledge sharing: an empirical analysis. International Journal of Human Resource Management, 14(7), pp. $1227-1245$ 


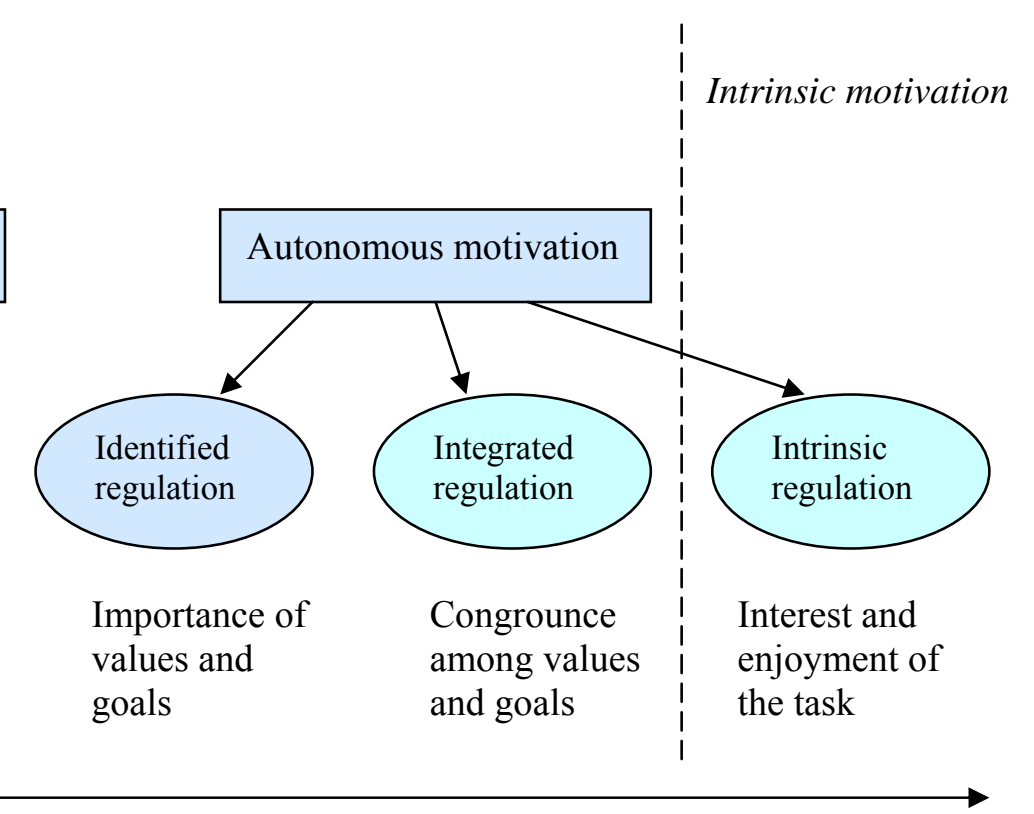

External PLOC /

Internal PLOC /

nonself-determined self-determined

(Adapted from Ryan and Deci, 2000) 
FIGURE 2: Model of Hypotheses

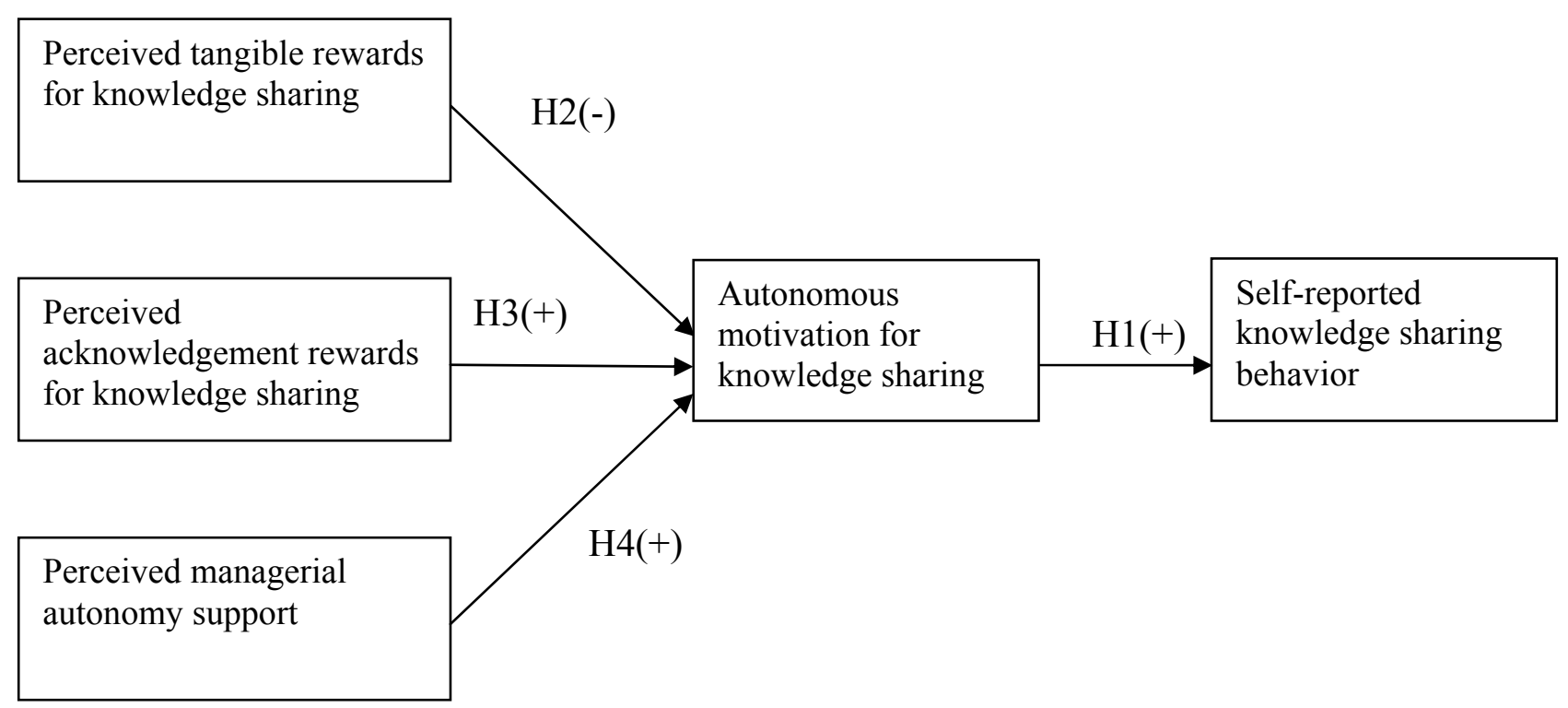


TABLE 1: Correlations

\begin{tabular}{|c|c|c|c|c|c|c|c|c|c|}
\hline \multicolumn{10}{|c|}{ Correlations between variables } \\
\hline & 1 & 2 & 3 & 4 & 5 & 6 & 7 & 8 & 9 \\
\hline $\begin{array}{l}\text { 1. Self-reported knowledge sharing } \\
\text { 2. Autonomous motivation } \\
\text { 3. Perceived tangible rewards } \\
\text { 4. Perceived acknowledgement rewards } \\
\text { 5. Perceived autonomy support } \\
\text { 6. Age } \\
\text { 7. Gender } \\
\text { 8. Duration of employment } \\
\text { 9. Controlled motivation }\end{array}$ & - & $0,59^{* *}$ & $\begin{array}{l}-0,23 \\
-0,18\end{array}$ & $\begin{array}{l}-0,06 \\
-0,07 \\
0,61^{* *}\end{array}$ & $\begin{array}{r}0,17 \\
0,47^{* *} \\
-0,07 \\
-0,09\end{array}$ & $\begin{array}{r}-0,45^{* *} \\
-0,26 \\
0,01 \\
0,03 \\
0,24\end{array}$ & $\begin{array}{c}-0,18 \\
-0,02 \\
0,05 \\
-0,13 \\
0,13 \\
-0,02\end{array}$ & $\begin{array}{r}-0,25 \\
-0,17 \\
-0,11 \\
-0,03 \\
0,12 \\
0,52^{* *} \\
0,09\end{array}$ & $\begin{array}{r}0,10 \\
0,24 \\
0,58^{* *} \\
0,34 \dagger \\
-0,05 \\
-0,36^{*} \\
-0,14 \\
-0,21\end{array}$ \\
\hline
\end{tabular}

$\dagger p<0.1 .{ }^{*} p<0.05 .{ }^{*} \mathrm{p}<0.01$ 
TABLE 2: Reasons for Sharing Knowledge

\begin{tabular}{|c|c|c|c|c|}
\hline \multicolumn{5}{|c|}{ Why do you share knowledge with others? } \\
\hline 1 - strongly disagree, 7 -strongly agree & Minimum & Maximum & Mean & Std. Deviation \\
\hline 1. I think it is an important part of my job & 2,00 & 7,00 & 6,13 & 1,04 \\
\hline $\begin{array}{l}\text { 2. Because sharing knowledge is an important } \\
\text { value for me }\end{array}$ & 2,00 & 7,00 & 5,66 & 1,04 \\
\hline 3. For the pleasure of discovering new insights & 2,00 & 7,00 & 5,66 & 1,18 \\
\hline 4. I find it personally satisfying & 2,00 & 7,00 & 5,41 & 1,27 \\
\hline 5. I enjoy doing so & 2,00 & 7,00 & 5,16 & 1,14 \\
\hline 6. I want to find out whether my ideas are relevant & 2,00 & 7,00 & 5,09 & 1,30 \\
\hline 7. I want my colleagues to think I am competent & 1,00 & 7,00 & 4,38 & 1,70 \\
\hline $\begin{array}{l}\text { 8. Because I would feel bad about myself if I did } \\
\text { not }\end{array}$ & 1,00 & 6,00 & 3,78 & 1,54 \\
\hline 9. I want my manager(s) to think well of me & 1,00 & 6,00 & 3,59 & 1,62 \\
\hline 10. I want my colleagues to praise me & 1,00 & 6,00 & 3,25 & 1,50 \\
\hline 11. I want my manager(s) to praise me & 1,00 & 6,00 & 3,25 & 1,50 \\
\hline 12. It may help me get promoted & 1,00 & 7,00 & 3,19 & 1,67 \\
\hline
\end{tabular}

Intrinsic motivation: 3, 4, 5; Identified motivation: 1, 2, 6

Introjected motivation: 7, 8, 9; External motivation: 10, 11, 12 
TABLE 3: Regression Results for Knowledge Sharing

\begin{tabular}{|c|c|c|c|c|}
\hline \multicolumn{5}{|c|}{ Regression results predicting knowledge sharing } \\
\hline \multirow[b]{2}{*}{ Variables } & \multicolumn{2}{|c|}{ Step 1} & \multicolumn{2}{|c|}{ Step 2} \\
\hline & (stand. $\beta$ ) & VIF & (stand. $\beta$ ) & VIF \\
\hline \multicolumn{5}{|l|}{ Step 1} \\
\hline Age & $-0.50^{*}$ & 1.52 & $-0.41^{*}$ & 1.55 \\
\hline Gender & 0.21 & 1.04 & 0.21 & 1.04 \\
\hline Duration of employment & 0.01 & 1.38 & 0.03 & 1.38 \\
\hline Controlled motivation & -0.10 & 1.18 & -0.19 & 1.21 \\
\hline \multicolumn{5}{|l|}{ Step 2} \\
\hline Autonomous motivation & & & $0.53^{* *}$ & 1.10 \\
\hline Adjusted $\mathrm{R}^{2}$ & 0.14 & & 0.41 & \\
\hline Adjusted $\Delta \mathrm{R}^{2}$ & 0.14 & & 0.27 & \\
\hline $\mathrm{F}$ & $2.25 \dagger$ & & $5.32^{* *}$ & \\
\hline$\Delta \mathrm{F}$ & $2.25 \dagger$ & & $13.44^{\star *}$ & \\
\hline
\end{tabular}


TABLE 4: Regression Results for Autonomous Motivation

\begin{tabular}{|c|c|c|c|c|}
\hline \multicolumn{5}{|c|}{ Regression results predicting autonomous motivation } \\
\hline \multirow[b]{2}{*}{ Variables } & \multicolumn{2}{|c|}{ Step 1} & \multicolumn{2}{|c|}{ Step 2} \\
\hline & (stand. $\beta$ ) & VIF & (stand. $\beta$ ) & VIF \\
\hline \multicolumn{5}{|l|}{ Step 1} \\
\hline Age & -0.18 & 1.52 & -0.18 & 1.87 \\
\hline Gender & -0.01 & 1.04 & -0.02 & 1.18 \\
\hline Duration of employment & -0.05 & 1.38 & -0.10 & 1.44 \\
\hline Controlled motivation & 0.17 & 1.18 & $0.41 \dagger$ & 2.01 \\
\hline \multicolumn{5}{|l|}{ Step 2} \\
\hline Tangible rewards & & & $-0.47 \dagger$ & 2.57 \\
\hline Acknowledgement rewards & & & 0.13 & 1.68 \\
\hline Autonomy support & & & $0.53^{* *}$ & 1.11 \\
\hline Adjusted R2 & 0.00 & & 0.33 & \\
\hline Adjusted $\Delta \mathrm{R} 2$ & 0.00 & & 0.33 & \\
\hline $\mathrm{F}$ & 0.69 & & $3.20^{*}$ & \\
\hline$\Delta \mathrm{F}$ & 0.69 & & $6.04^{* *}$ & \\
\hline
\end{tabular}

$\dagger \mathrm{p}<0.1 .{ }^{*} \mathrm{p}<0.05 .{ }^{* *} \mathrm{p}<0.01$ 
TABLE 5: Overview of Results

\begin{tabular}{|l|l|c|c|}
\hline Hypotheses & $\begin{array}{l}\text { Expected } \\
\text { direction }\end{array}$ & $\begin{array}{l}\text { Found } \\
\text { direction }\end{array}$ & $\begin{array}{l}\text { Support for } \\
\text { hypothesis }\end{array}$ \\
\hline $\begin{array}{l}\text { 1) The more autonomously motivated to share } \\
\text { knowledge, the more employees will engage in } \\
\text { knowledge sharing behavior }\end{array}$ & YES & YES \\
\hline $\begin{array}{l}\text { 2) The more employees perceive that } \\
\text { knowledge sharing leads to tangible rewards, } \\
\text { the less they will be autonomously motivated to } \\
\text { share knowledge }\end{array}$ & & NO \\
\hline $\begin{array}{l}\text { 3) The more employees perceive that } \\
\text { knowledge sharing leads to acknowledgement } \\
\text { rewards, the more they will be autonomously } \\
\text { motivated to share knowledge }\end{array}$ & & & YES \\
\hline $\begin{array}{l}\text { 4) The more employees perceive that managers } \\
\text { are autonomy supportive, the more they will be } \\
\text { autonomously motivated to share knowledge }\end{array}$ & & & \\
\hline
\end{tabular}




\begin{tabular}{|c|c|}
\hline CONSTRUCT & ITEM \\
\hline Knowledge Sharing & $\begin{array}{l}\text { To what extent do you agree with the following statements.. } \\
\text { 1. When I have knowledge that might be relevant for others in the } \\
\text { company, I do what I can to make it available to them } \\
\text { 2. When a colleague asks me for help or assistance, I share what } \\
\text { knowledge I may have on the subject } \\
\text { 3. I stay updated by exploring the information I can find on the } \\
\text { different knowledge systems and databases } \\
\text { 4. When I encounter a work related problem, I seek knowledge and } \\
\text { help from my colleagues }\end{array}$ \\
\hline $\begin{array}{l}\text { Autonomous } \\
\text { Motivation }\end{array}$ & $\begin{array}{l}\text { Why do you share knowledge with others? } \\
\text { 1. Because sharing knowledge is an important value for me } \\
\text { (identified) } \\
\text { 2. I want to find out whether my ideas are relevant (identified) } \\
\text { 3. I think it is an important part of my job (identified) } \\
\text { 4. I enjoy doing so (intrinsic) } \\
\text { 5. I find it personally satisfying (intrinsic) } \\
\text { 6. For the pleasure of discovering new insights (intrinsic) }\end{array}$ \\
\hline $\begin{array}{l}\text { Controlled } \\
\text { Motivation }\end{array}$ & $\begin{array}{l}\text { Why do you share knowledge with others? } \\
\text { 1. Because I would feel bad about myself if I did not (introjected) } \\
\text { 2. I want my colleagues to think I am competent (introjected) } \\
\text { 3. I want my manager(s) to think well of me (introjected) } \\
\text { 4. I want my manager(s) to praise me (external) } \\
\text { 5. It may help me get promoted (external) } \\
\text { 6. I want my colleagues to praise me (external) }\end{array}$ \\
\hline $\begin{array}{l}\text { Managerial } \\
\text { Autonomy Support }\end{array}$ & $\begin{array}{l}\text { To what extent do you agree with the following statements.. } \\
\text { 1. I feel that my manager(s) provide me choices and options about } \\
\text { how to do my job and how to handle problems I encounter } \\
\text { 2. I feel understood by my manager(s) } \\
\text { 3. My manager(s) convey confidence in my ability to do well at my } \\
\text { job } \\
\text { 4. My manager(s) encourage me to ask questions } \\
\text { 5. My manager(s) listen to how I would like to do things } \\
\text { 6. My manager(s) try to understand how I see things before } \\
\text { suggesting a new way to do things }\end{array}$ \\
\hline
\end{tabular}




\begin{tabular}{|l|l|}
\hline CONSTRUCT & ITEM \\
\hline Perceived Tangible & To what extent do you experience that your engagement in \\
Rewards & knowledge sharing leads to.. \\
& $\begin{array}{l}\text { 1. Salary increases? } \\
\text { 2. Better chances for advancement or promotion? }\end{array}$ \\
\hline 3erceived & To what extent do you experience that your engagement in \\
Acknowledgement & knowledge sharing leads to.. \\
Rewards & $\begin{array}{l}\text { 1. Positive feedback from my manager(s)? } \\
\text { 2. Acknowledgement from my colleagues? } \\
\end{array}$ \\
& 3. Acknowledgement from my manager(s)? \\
\hline
\end{tabular}




\section{SMG - Working Papers \\ www.cbs.dk/smg \\ 2003}

2003-1: Nicolai J. Foss, Kenneth Husted, Snejina Michailova, and Torben Pedersen: Governing Knowledge Processes: Theoretical Foundations and Research Opportunities.

2003-2: Yves Doz, Nicolai J. Foss, Stefanie Lenway, Marjorie Lyles, Silvia Massini, Thomas P. Murtha and Torben Pedersen: Future Frontiers in International Management Research: Innovation, Knowledge Creation, and Change in Multinational Companies.

2003-3: Snejina Michailova and Kate Hutchings: The Impact of In-Groups and OutGroups on Knowledge Sharing in Russia and China CKG Working Paper.

2003-4: Nicolai J. Foss and Torben Pedersen : The MNC as a Knowledge Structure: The Roles of Knowledge Sources and Organizational Instruments in MNC Knowledge Management CKG Working Paper.

2003-5: Kirsten Foss, Nicolai J. Foss and Xosé H. Vázquez-Vicente: “Tying the Manager's Hands": How Firms Can Make Credible Commitments That Make Opportunistic Managerial Intervention Less Likely CKG Working Paper.

2003-6: Marjorie Lyles, Torben Pedersen and Bent Petersen: Knowledge Gaps: The Case of Knowledge about Foreign Entry.

2003-7: Kirsten Foss and Nicolai J. Foss: The Limits to Designed Orders: Authority under "Distributed Knowledge" CKG Working Paper.

2003-8: Jens Gammelgaard and Torben Pedersen: Internal versus External Knowledge Sourcing of Subsidiaries - An Organizational Trade-Off.

2003-9: Kate Hutchings and Snejina Michailova: Facilitating Knowledge Sharing in Russian and Chinese Subsidiaries: The Importance of Groups and Personal Networks Accepted for publication in Journal of Knowledge Management.

2003-10: Volker Mahnke, Torben Pedersen and Markus Verzin: The Impact of Knowledge Management on MNC Subsidiary Performance: the Role of Absorptive Capacity CKG Working Paper.

2003-11: Tomas Hellström and Kenneth Husted: Mapping Knowledge and Intellectual Capital in Academic Environments: A Focus Group Study Accepted for publication in Journal of Intellectual Capital CKG Working Paper.

2003-12: Nicolai J Foss: Cognition and Motivation in the Theory of the Firm: Interaction or "Never the Twain Shall Meet"? Accepted for publication in Journal des Economistes et des Etudes Humaines CKG Working Paper.

2003-13: Dana Minbaeva and Snejina Michailova: Knowledge Transfer and Expatriation Practices in MNCs: The Role of Disseminative Capacity.

2003-14: Christian Vintergaard and Kenneth Husted: Enhancing Selective Capacity Through Venture Bases. 


\section{4}

2004-1: Nicolai J. Foss: Knowledge and Organization in the Theory of the Multinational Corporation: Some Foundational Issues

2004-2: Dana B. Minbaeva: HRM Practices and MNC Knowledge Transfer

2004-3: Bo Bernhard Nielsen and Snejina Michailova: Toward a Phase-Model of Global Knowledge Management Systems in Multinational Corporations

2004-4: Kirsten Foss \& Nicolai J Foss: The Next Step in the Evolution of the RBV: Integration with Transaction Cost Economics

2004-5: Teppo Felin \& Nicolai J. Foss: Methodological Individualism and the Organizational Capabilities Approach

2004-6: Jens Gammelgaard, Kenneth Husted, Snejina Michailova: Knowledge-sharing Behavior and Post-acquisition Integration Failure

2004-7: Jens Gammelgaard: Multinational Exploration of Acquired R\&D Activities

2004-8: Christoph Dörrenbächer \& Jens Gammelgaard: Subsidiary Upgrading? Strategic Inertia in the Development of German-owned Subsidiaries in Hungary

2004-9: Kirsten Foss \& Nicolai J. Foss: Resources and Transaction Costs: How the Economics of Property Rights Furthers the Resource-based View

2004-10: Jens Gammelgaard \& Thomas Ritter: The Knowledge Retrieval Matrix: Codification and Personification as Separate Strategies

2004-11: Nicolai J. Foss \& Peter G. Klein: Entrepreneurship and the Economic Theory of the Firm: Any Gains from Trade?

2004-12: Akshey Gupta \& Snejina Michailova: Knowledge Sharing in Knowledge-Intensive Firms: Opportunities and Limitations of Knowledge Codification

2004-13: Snejina Michailova \& Kate Hutchings: Knowledge Sharing and National Culture: A Comparison Between China and Russia

\section{5}

2005-1: Keld Laursen \& Ammon Salter: My Precious - The Role of Appropriability Strategies in Shaping Innovative Performance

2005-2: Nicolai J. Foss \& Peter G. Klein: The Theory of the Firm and Its Critics: A Stocktaking and Assessment

2005-3: Lars Bo Jeppesen \& Lars Frederiksen: Why Firm-Established User Communities Work for Innovation: The Personal Attributes of Innovative Users in the Case of Computer-Controlled Music

2005-4: Dana B. Minbaeva: Negative Impact of HRM Complementarity on Knowledge Transfer in MNCs

2005-5: Kirsten Foss, Nicolai J. Foss, Peter G. Klein \& Sandra K. Klein: Austrian Capital 
Theory and the Link Between Entrepreneurship and the Theory of the Firm

2005-1: Nicolai J. Foss: The Knowledge Governance Approach

2005-2: Torben J. Andersen: Capital Structure, Environmental Dynamism, Innovation Strategy, and Strategic Risk Management

2005-3: Torben J. Andersen: A Strategic Risk Management Framework for Multinational Enterprise

2005-4: Peter Holdt Christensen: Facilitating Knowledge Sharing: A Conceptual Framework

2005-5 Kirsten Foss \& Nicolai J. Foss: Hands Off! How Organizational Design Can Make Delegation Credible

2005-6 Marjorie A. Lyles, Torben Pedersen \& Bent Petersen: Closing the Knowledge Gap in Foreign Markets - A Learning Perspective

2005-7 Christian Geisler Asmussen, Torben Pedersen \& Bent Petersen: How do we Capture "Global Specialization" when Measuring Firms' Degree of internationalization?

2005-8 Kirsten Foss \& Nicolai J. Foss: Simon on Problem-Solving: Implications for New Organizational Forms

2005-9 Birgitte Grøgaard, Carmine Gioia \& Gabriel R.G. Benito: An Empirical Investigation of the Role of Industry Factors in the Internationalization Patterns of Firms

2005-10 Torben J. Andersen: The Performance and Risk Management Implications of Multinationality: An Industry Perspective

2005-11 Nicolai J. Foss: The Scientific Progress in Strategic Management: The case of the Resource-based view

2005-12 Koen H. Heimeriks: Alliance Capability as a Mediator Between Experience and Alliance Performance: An Empirical Investigation Into the Alliance Capability Development Process

2005-13 Koen H. Heimeriks, Geert Duysters \& Wim Vanhaverbeke: Developing Alliance Capabilities: An Empirical Study

2005-14 JC Spender: Management, Rational or Creative? A Knowledge-Based Discussion

\section{6}

2006-1: Nicolai J. Foss \& Peter G. Klein: The Emergence of the Modern Theory of the Firm

2006-2: Teppo Felin \& Nicolai J. Foss: Individuals and Organizations: Thoughts on a Micro-Foundations Project for Strategic Management and Organizational Analysis

2006-3: Volker Mahnke, Torben Pedersen \& Markus Venzin: Does Knowledge Sharing 
Pay? An MNC Subsidiary Perspective on Knowledge Outflows

2006-4: Torben Pedersen: Determining Factors of Subsidiary Development

2006-5 Ibuki Ishikawa: The Source of Competitive Advantage and Entrepreneurial Judgment in the RBV: Insights from the Austrian School Perspective

2006-6 Nicolai J. Foss \& Ibuki Ishikawa: Towards a Dynamic Resource-Based View: Insights from Austrian Capital and Entrepreneurship Theory

2006-7 Kirsten Foss \& Nicolai J. Foss: Entrepreneurship, Transaction Costs, and Resource Attributes

2006-8 Kirsten Foss, Nicolai J. Foss \& Peter G. Klein: Original and Derived Judgement: An Entrepreneurial Theory of Economic Organization

2006-9 Mia Reinholt: No More Polarization, Please! Towards a More Nuanced Perspective on Motivation in Organizations

2006-10 Angelika Lindstrand, Sara Melen \& Emilia Rovira: Turning social capital into business? A study of Swedish biotech firms' international expansion

2006-11 Christian Geisler Asmussen, Torben Pedersen \& Charles Dhanaraj: Evolution of Subsidiary Competences: Extending the Diamond Network Model

2006-12 John Holt, William R. Purcell, Sidney J. Gray \& Torben Pedersen: Decision Factors Influencing MNEs Regional Headquarters Location Selection Strategies

2006-13 Peter Maskell, Torben Pedersen, Bent Petersen \& Jens Dick-Nielsen: Learning Paths to Offshore Outsourcing - From Cost Reduction to Knowledge Seeking

2006-14 Christian Geisler Asmussen: Local, Regional or Global? Quantifying MNC Geographic Scope

2006-15 Christian Bjørnskov \& Nicolai J. Foss: Economic Freedom and Entrepreneurial Activity: Some Cross-Country Evidence

2006-16 Nicolai J. Foss \& Giampaolo Garzarelli: Institutions as Knowledge Capital: Ludwig M. Lachmann's Interpretative Institutionalism

2006-17 Koen H. Heimriks \& Jeffrey J. Reuer: How to Build Alliance Capabilities

2006-18 Nicolai J. Foss, Peter G. Klein, Yasemin Y. Kor \& Joseph T. Mahoney: Entrepreneurship, Subjectivism, and the Resource - Based View: Towards a New Synthesis

2006-19 Steven Globerman \& Bo B. Nielsen: Equity Versus Non-Equity International Strategic Alliances: The Role of Host Country Governance

\section{7}

2007-1 Peter Abell, Teppo Felin \& Nicolai J. Foss: Building Micro-Foundations for the Routines, Capabilities, and Performance Links 
2007-2 Michael W. Hansen, Torben Pedersen \& Bent Petersen: MNC Strategies and Linkage Effects in Developing Countries

2007-3 Niron Hashai, Christian G. Asmussen, Gabriel R.G. Benito \& Bent Petersen: Predicting the Diversity of Foreign Entry Modes

2007-4 Peter D. Ørberg Jensen \& Torben Pedersen: Whether and What to Offshore?

2007-5 Ram Mudambi \& Torben Pedersen: Agency Theory and Resource Dependency Theory: Complementary Explanations for Subsidiary Power in Multinational Corporations

2007-6 Nicolai J. Foss: Strategic Belief Management

2007-7 Nicolai J. Foss: Theory of Science Perspectives on Strategic Management Research: Debates and a Novel View

2007-8 Dana B. Minbaeva: HRM Practices and Knowledge Transfer in MNCs

2007-9 Nicolai J. Foss: Knowledge Governance in a Dynamic Global Context: The Center for Strategic Management and Globalization at the Copenhagen Business School

2007-10 Paola Gritti \& Nicolai J. Foss: Customer Satisfaction and Competencies: An Econometric Study of an Italian Bank

2007-11 Nicolai J. Foss \& Peter G. Klein: Organizational Governance

2007-12 Torben Juul Andersen \& Bo Berhard Nielsen: The Effective Ambidextrous Organization: A Model of Integrative Strategy Making Processes.

\section{8}

2008-1 Kirsten Foss \& Nicolai J. Foss: Managerial Authority When Knowledge is Distributed: A Knowledge Governance Perspective

2008-2 Nicolai J. Foss: Human Capital and Transaction Cost Economics.

2008-3 Nicolai J. Foss \& Peter G. Klein: Entrepreneurship and Heterogeneous Capital.

2008-4 Nicolai J. Foss \& Peter G. Klein: The Need for an Entrepreneurial Theory of the Firm.

2008-5 Nicolai J. Foss \& Peter G. Klein: Entrepreneurship: From Opportunity Discovery to Judgment.

2008-6 Mie Harder: How do Rewards and Management Styles Influence the Motivation to Share Knowledge? 